\title{
The Jewish Autonomous Oblast in the USSR in THe Documents OF THE BRITISH FOREIGN OfFICE (1952-1958)
}

\author{
Artur Patek \\ https://orcid.org/0000-0002-6435-142X \\ (Jagiellonian University, Krakow) \\ e-mail: artur.patek@uj.edu.pl
}

Keywords: Jewish Autonomous Oblast, Birobijan, Foreign Office, Jews in the USSR

\begin{abstract}
The Jewish Autonomous Oblast known as Birobijan in the USSR attracted the interest of the British diplomacy. This is reflected in the correspondence between British missions in the USSR and Israel and the Foreign Office. This analysis covers five documents from 1952-1958 kept in the National Archives in London. The documents pertain to two matters: (1) a discussion about the current status of the Jewish Autonomous Oblast (whether rumours of its disappearance were true) and (2) reflections on the actual character of the oblast (to what extent it was Jewish and autonomous). The significance of these documents can be analysed on several levels - from the viewpoint of Birobijan's history, the nature of British-Soviet relations, and the operating methods of diplomatic services. Reading the documents leads to several questions: why was Great Britain interested in the oblast? How was it perceived in the West? How did the Foreign Office obtain information about it?
\end{abstract}

The propagandist image of Birobijan as the proletariat homeland of Jews in the USSR captured the imagination of journalists and politicians, as well as ordinary people. Officially, the region was named the Jewish Autonomous Oblast, but almost everybody referred to it by the name of its capital and main city, Birobijan. The oblast was supposed to be the Kremlin's response to the building of the Jewish national home in Palestine. It did not become a second "promised land." What it was, however, was an attempt to form a Communist community which was supposed to cut itself off from its Jewish roots, forget about the existence of its religion and history, and start everything anew. ${ }^{1}$

The project, widely publicized at one time, ended in failure. In fact, it was doomed to fail from its very beginning in 1928, when the Central Executive Committee of the USSR issued a decree "on the attaching of the Birobijan region for settlement of working Jews." 2 The project failed for several reasons: (a) the oblast was created by an arbitrary

${ }^{1}$ Works about the history of the oblast include (in chronological order) e.g.: Lvavi (Babitzky) 1965; Schwarz 1969: 342-395; Patek 1997; Weinberg 1998; Gurevich, Ryanskii (eds.) 1999; Kuchenbecker 2000; Srebrnik 2010; Nivat 2013; Gessen 2016; Maksimowska 2019.

2 The text of the decree (in Russian): Lvavi (Babitzky) 1965: 350-351. In August 1930, the Jewish National Raion was established, which was transformed into the Jewish Autonomous Oblast within the Russian Soviet Federative Socialist Republic four years later (in May 1934). The texts of both proclamations: Patek 1997: 76-77, 79. 
decision of the government, which was guided by ideological and political factors; (b) it was an experiment on a living organism; (c) it did not take into account the specificity of the Jewish community and was not approved by it; (d) there were no emotional or historical ties between the oblast and Jews (how could the slogan "Birobijan is our Zion" appeal to Jews?); (e) the government treated the region in a calculating way practically the entire time, using it for its short-term political and propagandist purposes.

Attracting a larger number of Jewish settlers was unsuccessful. As the official statistics showed, towards the end of the USSR 8,887 Jews lived in the oblast, only 0.64 percent of the entire Jewish population of the country. In "their" oblast, they were a small minority (4.2 percent of the population), which continued to decrease due to emigration. ${ }^{3}$ However, dissolving the oblast was out of the question, since it would force the Kremlin to admit to an ideological defeat.

In 1951, The New York Times, The Observer, and The Jewish Chronicle published news about the alleged liquidation of the oblast. ${ }^{4}$ It was not confirmed, but the British diplomacy noted it with a great deal of attention. It was difficult to ignore, since the articles were published in serious newspapers and expressed the opinions of experienced journalists, the American Harry Schwartz and the Briton Edward Crankshaw. They both had had experience cooperating with their countries' intelligence (during WWII) and specialised in Soviet affairs.

Rumours of the oblast's liquidation did not appear at that particular time by accident. In the late 1940s in the USSR, an anti-Semitic campaign against the so-called "rootless cosmopolitans" started. The dissolution of the Jewish Anti-Fascist Committee (Yevreysky antifashistsky komitet) and arrests of its leading members in 1948 is regarded as the symbolic start of this campaign. ${ }^{5}$ Absurd accusations of spy activity and the intention to establish a "bourgeois Zionist republic" in the Crimea became the pretext. The majority of the institutions using Yiddish were closed down (including educational institutions, theatres, etc.) and the language virtually disappeared from public life. Repressions decimated the local elites, and culminated in the Moscow trial of the oblast's leaders, which took place at the turn of 1951 and $1952 .{ }^{6}$ As the Israeli journalist of Polish descent, Yehoshua A. Gilboa, vividly put it, the only traces of Birobijan's Jewishness were bilingual signs in the streets, on office buildings, and at the railway station. ${ }^{7}$

The exchange of correspondence about Birobijan started with a letter of the British Embassy in Moscow, dated 23 October 1952, addressed to the British Chancery in Tel Aviv. ${ }^{8}$ Following the established procedure, the note was also copied to the Foreign Office's Eastern Department, which was in charge of relations with Middle East

3 Heitman 1990: 26.

4 The National Archives, London (TNA) FO 371/98797, Letter of the Foreign Office's Eastern Department to the British Chancery in Moscow, 24 November 1952. The text of the letter is quoted in the Appendix (document 1).

5 For more see Lustiger 2004; Brent, Naumov 2003.

${ }^{6}$ Maltinsky 1981. Chaim Maltinski was a journalist and one of the accused in the trial. He was sentenced to exile, which he served in Vologda. After his release, he managed to leave for Israel. For repressions in 1948-1953 see: Levin 1988: 508-510, 535-539; Weinberg 1998: 82-85.

7 Gilboa 1971: 196. As a Gulag prisoner, Gilboa (b. 1918 in Pinsk in pre-war Poland, in Israel since 1949) experienced Stalinist reality first-hand.

${ }^{8}$ The note was also copied to the British Middle East Office in Egypt. TNA. FO 371/98797, Letter of the British Chancery in Moscow to the British Chancery in Tel Aviv, 23 October 1952. In fact, the British 
countries. The main topic of the letter was the speech of Shmuel Mikunis, the leader of the Communist Party of Israel, given at the XIX Congress of the Communist Party of the Soviet Union (Bolsheviks). ${ }^{9}$ The note mentioned in passing the disappearance of the oblast and it was this that drew the attention of the Foreign Office. As we have stated, rumours about this had been circulating for some time, but this time things looked different. The news came from Moscow, through confidential diplomatic channels. It needed to be clarified, and first of all, it had to be established on what basis this communiqué had been prepared. Therefore, an enquiry was sent to the Moscow office, and the Foreign Office's Eastern Department also copied it to the Chancery in Tel Aviv. ${ }^{10}$ This indicated considerable interest on London's part.

The Foreign Office's note reveals that specialised units of the office, the Research Department ${ }^{11}$ and the Information Research Department, ${ }^{12}$ carefully analysed news coming from the Soviet media, including more remote outlets such as the radio stations in Khabarovsk and Birobijan. It was in Far East radio broadcasts that indirect but strong arguments for the oblast's continued existence were found. Khabarovsk Radio, during a broadcast on 7 August 1951, reportedly informed listeners about the Executive Committee of the oblast being awarded a Red Banner for "exceeding the plan for collecting non-ferrous scrap," "13 and a year later (on 29 September 1952) regional Birobijan Radio, speaking about one of the local industrial combines, clearly referred to its location as the "Jewish Autonomous Oblast." only information about the alleged liquidation of the oblast came from a few Western newspapers, but it has thus far been impossible to confirm the news. ${ }^{15}$

Characteristically, the British Chancery in Moscow, replying to the letter from the Foreign Office's Eastern Department, did not offer clear evidence for or against. It laconically admitted that the reference to the "disappearance" of the oblast was an "oversimplification." As an explanation, it added that with the change of the Soviet government's policy towards the Jews, the original conception of Birobijan as "the second national Jewish home" radically changed, and although the oblast continued to function

Chancery had by then (September 1952) been promoted to the rank of an embassy. Israel Government YearBook 1953: 154.

9 The congress was in session in Moscow on 5-14 October 1952. Two delegates of the Communist Party of Israel participated: Shmuel Mikunis and Tavfik Toubi (a politician of Arabic descent). TNA. FO 371/98797, Letter of the British Chancery in Moscow to the Chancery in Tel Aviv, 23 October 1952.

${ }^{10}$ TNA. FO 371/98797, Letter of the Foreign Office's Eastern Department to the British Chancery in Moscow, 24 November 1952.

${ }^{11}$ The Foreign Office Research Department (FORD) - a unit of the Foreign Office created in 1943, which prepared historical analyses and foreign press reviews of political matters, etc. It was later transformed into the Research and Analysis Department of the Foreign and Commonwealth Office. Longmire, Walker 1995.

${ }^{12}$ The Information Research Department - a confidential department of the Foreign Office, which existed in 1948-1977. Its task was to counteract Soviet propaganda and infiltration. Defty 2004.

${ }^{13}$ This information was impossible to confirm. It is more probable that the award was the Order of the Red Banner of Labour, given for contributions in science, culture and the arts, the development of the national economy, etc. The Order of the Red Banner was a military decoration, awarded for heroism and courage on the battlefield.

${ }^{14}$ TNA. FO 371/98797, Letter of the Foreign Office's Eastern Department to the British Chancery in Moscow, 24 November 1952.

${ }_{15} \mathrm{Ibid}$.The correspondence quotes the mentioned pieces in The New York Times, The Observer and The Jewish Chronicle, all from 1951. 
as an administrative entity, it was mostly in a formal sense. ${ }^{16}$ This exceptional briefness, not to say vagueness, of the answer was telling. It may have indicated the difficulty in obtaining information encountered by representatives of Western countries in the USSR.

More light was shed on the matter by a note which came to London from the British Chancery in Tel Aviv. It turned out that the Foreign Office's letter prompted this office's staff to consult the opinion of the head of Israeli diplomacy, Moshe Sharett. They learned that the oblast still existed, but it said a lot about its true nature that out of the two delegates from Birobijan to the latest (XIX) congress of the Bolshevik party, neither was a Jew. ${ }^{17}$ The Jewish population remained a minority concentrated in towns, and the entire experiment of settling Jews in the Far East ended in failure. ${ }^{18}$

It is worth noting the information about the delegation to the party congress in Moscow. It was referenced deliberately. In the Soviet reality, some topics were not mentioned directly. One had to read between the lines. For instance, if the press suddenly stopped mentioning a subject or, conversely, emphasised one, it was always for a reason. One example of the British gleaning seemingly insignificant information out of official news reports was recording (just in case?) the names of the two Birobijan representatives who participated in the party conference of Khabarovsk Krai in 1952. ${ }^{19}$

It is unsurprising that the diplomats from the Moscow Embassy did not ask one of the Soviet officials about the oblast's status. Could they have expected to receive a transparent answer, especially if it put the USSR's government in an unfavourable light? The last years of Stalin's life were the height of the Cold War, and relations between the Kremlin and London (and more broadly between the Kremlin and Western countries) were rife with mutual distrust. The issue of Birobijan's administrative status may have appeared insignificant, but in the Cold War atmosphere it was perfect to use for propagandist purposes, for various reasons. ${ }^{20}$

Analysing the correspondence of the Foreign Office from November and December 1952 , it is difficult not to form the impression that the USSR government quite effectively cut off the oblast's contact with the outside world. To what degree must have Birobijan been isolated, if the British diplomacy could not definitively confirm the seemingly simple fact of whether the Jewish Autonomous Oblast still existed as a separate administrative unit? To answer this question, the British undertook actions which bordered on detective work, analysing various broadcasts and indirect accounts, asking abroad (in Israel), and drawing conclusions on this basis. The steps taken by the Foreign Office indicate how very totalitarian Stalin's USSR was, if it managed to dole out information to foreign diplomats accredited in Moscow so carefully.

16 TNA. FO 371/98797, Letter of the British Chancery in Moscow to the Foreign Office's Eastern Department, 4 December 1952. See Appendix, document 2.

17 TNA. FO 371/98797, Letter of the British Chancery in Tel Aviv to the Foreign Office's Eastern Department, 16 December 1952. See Appendix, document 3.

18 Ibid.

19 The information was obtained from a regional radio broadcast in the USSR. TNA. FO 371/98797, a hand-written note made in the Foreign Office's Eastern Department, which accompanied the letter from the British Chancery in Tel Aviv, undated. Khabarovsk Krai (part of the Russian Soviet Federative Socialist Republic) was the oblast's neighbour, surrounding it from the east and north.

${ }_{20}$ The potential interest of the numerous Jewish Diaspora in Great Britain, which was estimated at 450,000 people, may have been of importance here. Shapiro 1952: 234. 
The topic of Birobijan also appeared in later correspondence. As we can deduce from the extant documents, these matters did not absorb the British in any particular way, but when some interesting information appeared, the Embassy in Moscow noted it and passed it on to the central office in London. It was directed to the Foreign Office's Northern Department, which at that time, contrary to its name, was in charge of Great Britain's relations with the USSR and the Warsaw Pact countries. ${ }^{21}$

It seems that the British diplomacy was aware of the actual significance of the Jewish Autonomous Oblast. In fact, Birobijan was on the peripheries of Jewish life in the USSR, not only geographically. In this context, it is understandable why in a several-page report on the Jewish situation (prepared by the British Embassy in Moscow in May 1956) the issue of Birobijan was summed up in just one sentence. ${ }^{22}$ The propagandist and ideological sense of the Birobijan project was understood as well.

Since the truth about the oblast was carefully hidden for many years, and then - after Stalin's death - very unwillingly revealed, the accounts of the persons who managed to go there were of particular significance. However, the Soviet government strictly restricted the access of foreign visitors to Birobijan. One of the handful who were allowed in was the American journalist Harrison Evans Salisbury (1908-1993), a correspondent for The New York Times for many years who went on to win the Pulitzer Prize. After his return, in June 1954, he published a report in The New York Times which ended with the conclusion that the oblast was indeed dead as a Jewish centre. ${ }^{23}$ The Kremlin's response to this was reflected in the fact that over the next few years no other foreign journalist visited the Jewish Autonomous Oblast. ${ }^{24}$

Therefore, when the Israeli ambassador Yosef Avidar visited the oblast in June 1956, the British diplomacy showed an interest. ${ }^{25}$ As we can assume from the surviving correspondence, the topic of Birobijan was mentioned in Avidar's conversation with the British ambassador, William Goodenough Hayter. ${ }^{26}$ The Israeli summed up his impressions from the visit in a brief but telling way: out of the three words which made up the region's official name (Yevreyskaya avtonomnaya oblast) only one - the last one - was true. The autonomy existed on paper, and the oblast was Jewish to only a very slight degree. ${ }^{27}$

${ }^{21}$ See the memoirs of Department employee James Reeve (1999: 122-130).

22 Birobidjan, which was organised as a special Jewish oblast, is now never referred to as being specifically Jewish. TNA. FO 371/122938, Letter of the British Chancery in Moscow to the Foreign Office's Northern Department, 25 May 1956: 2.

${ }_{23}$ Salisbury 1955: 281-284; Salisbury 1954: 6. Salisbury was the bureau chief of The New York Times in Moscow in 1949-1954.

${ }^{24}$ It was not until 1958 and 1959 that journalists (including ones from Poland and East Germany) appeared there. Linde, Meissgeier 1960; Horodyński 1958: 18-19; Horodyński 1959: 53-72. Horodyński’s companions on the trip to "lesser-known regions of the USSR" were the writer Roman Bratny, the painter and graphic artist Andrzej Strumiłło, and the journalist Bohdan Kutyłowski. The author admitted that "the experiment of turning Jews into farmers and settling them east of the Mongolian border, where there had been no Jewish tradition, could not have ended in a complete success. However, he did not (could not?) write openly that they were a tiny minority in the oblast, merely stating briefly that a percentage of Jews live here" (whereas it was emphasised that in the capital city of Birobijan they reportedly made up half of the population).

${ }^{25}$ Avidar and his wife visited Birobijan in June 1956. Y. Ro'i (introduced and annotated by) 2009: $141 \mathrm{ff}$.

${ }^{26}$ TNA. FO 371/122938, Letter of the British Chancery in Moscow to the Foreign Office's Northern Department, 20 July 1956. Cf. the Appendix, document 4.

27 Ibid. 
The Moscow office informed the London central office about Avidar's observations. The British recorded that none of the schools conducted classes in Yiddish, and the language was not even taught as a separate subject. ${ }^{28}$ This must have raised eyebrows, since the language formally continued to function as one of the two official languages in the oblast (the other being Russian). In the quoted note, there are more indications confirming the fiasco of the Birobijan experiment (see Appendix, document 4). The information not only offered specific knowledge about the USSR's ethnic policy, but in favourable circumstances it could also have been suitably used, e.g. for propagandist purposes.

Avidar's visit to Birobijan was a sign of the Kremlin's somewhat liberalised policy in the wake of de-Stalinisation. It is worth noting that a few weeks earlier, in May 1956, the British Embassy in Moscow informed the Foreign Office that the personnel of the Israeli Embassy had been cut off from contacts with Russian Jews, and those who communicated with the Israeli office continued to have enormous problems. ${ }^{29}$

The news published by the Soviet media continued to be monitored. In previous years, information about Birobijan had rarely appeared in the USSR public space. Therefore, a lengthy article published in August 1958 in Sovetskaya Rossiya under the characteristic title of "Yevreyskaya avtonomiya" ("Jewish autonomy"), could not have escaped the attention of the British. ${ }^{30}$

The article was intriguing for several reasons: (a) Sovetskaya Rossiya at the time was the press organ of the Supreme Soviet and Council of Ministers of the Russian SFSR, which meant that the texts it published reflected the official line of the party and state policies; (b) it revealed signs of Jewish cultural life in the oblast (the text mentions, among others, the press and radio broadcasts in Yiddish and the activity of local Jewish artists); (c) it argued that new settlers continued to arrive in the Birobijan region; (d) it contrasted the allegedly depressing lot of those who believed "Zionist propaganda" and emigrated from Birobijan to Israel; (e) the author's interviewees included only persons of Jewish descent (their ethnicity was emphasised by their names and patronymics). A reader with poor knowledge of the Soviet reality could have got the impression that building a "Jewish autonomy" in the oblast was indeed a success.

It followed from the note prepared by the British Embassy in Moscow that the British had no doubts about the propagandist nature of this text. ${ }^{31}$ They had reports from Birobijan. In March 1957, one of the Embassy's employees probably visited the oblast and his observations painted a completely different picture. ${ }^{32}$ The British noted the lack of activities key to maintaining the Jewish ethnic identity in the oblast. Where was the young generation supposed to learn Jewish traditions, customs and language, if none of the schools taught Yiddish and the synagogue building damaged by fire continued to sit unrepaired? ${ }^{33}$

28 Ibid.

${ }_{29}$ TNA. FO 371/122938, Letter of the British Chancery in Moscow to the Foreign Office's Northern Department, 25 May 1956, 2.

${ }^{30}$ Pakhman 1958: 3. Reprint translated into English: Sovetskaya Rossia Lauds Jewish Life in Birobidzhan 1958: 12-13; lengthy fragments in: Pinkus 1984: 381-382; Patek 1997: 89-90.

31 TNA. FO 371/135342, Letter of the British Chancery in Moscow to the Foreign Office's Northern Department, 11 August 1958. See Appendix, document 5.

32 Ibid., see fn. 66.

33 The synagogue in the city of Birobijan probably burnt down in 1956 . The accident happened as a result of a fire in a nearby factory. Ibid.; TNA. FO 371/122938, Letter of the British Chancery in Moscow of 20 July 1956. 
A newspaper in Yiddish was published, but it imposed a worldview foreign to Jewish ethnic values. The slight Jewish cultural activity allowed by Moscow did have some significance for maintaining their identity, but in allowing this activity the authorities were guided by their own political reasons.

The publication in Sovetskaya Rossiya could not have been a coincidence. The British speculated that it might be indicating a change of the USSR's policy towards the Jews and an attempt at reanimating the Birobijan experiment. ${ }^{34}$ Birobijan did in fact make more noise soon afterwards. Moscow Radio aired a series of broadcasts about the oblast, and in 1959, on the 25 th anniversary of its establishment, the first publication in years was released about it. ${ }^{35}$

It cannot be ruled out that this increase of interest in the oblast had other reasons behind it, and that the point might have been to erase the unpleasant impression made by an interview that Nikita Khrushchev had given with the French newspaper Le Figaro. ${ }^{36}$ The Soviet leader in fact admitted that the Jewish settlement in Birobijan had ended in failure. In his characteristic style, he concluded that this was due to the fact that Jews were "individualists" and did not like "group discipline." 37 They preferred to work in trade and crafts rather than in industry or farming. One could feel animosity towards Jews in these words, and this is how they were read in the West. The article in Sovetskaya Rossiya indirectly disclaimed everything Khrushchev had said.

Of what value to a historian are the documents of the British diplomacy cited here? Their significance can be analysed on several levels: from the viewpoint of the history of Birobijan, the nature of British-Soviet relations, and the methods employed by diplomatic services. Their reading leads to several questions. Why did the Jewish Autonomous Oblast attract the interest of Great Britain? How was it perceived in the West? How did the Foreign Office obtain information about Birobijan? Why did the USSR restrict access to reliable information about the oblast? These questions can be a springboard for further, more detailed research.

Let us try to draw clear conclusions and make observations on the basis of an analysis of the documents in question.

(1) Birobijan was isolated by Moscow from contact with foreign countries throughout the majority of the time period in question. Information about it was almost nonexistent, since the Kremlin did not want to admit an ideological failure. This meant that various speculations appeared in the West; it was not ruled out that the oblast could have been liquidated as a separate administrative unit. It seems that the British were essentially aware of the truth, of what the so-called Jewish autonomy was really like. Therefore, they were highly distrustful of the surprising article in Sovetskaya Rossiya and tried to get to the bottom of the reasons for its publication. Side effects of the USSR doling out information about Birobijan were some imprecise phrases in

34 TNA. FO 371/135342, Letter of the British Chancery in Moscow to the Foreign Office's Northern Department, 11 August 1958.

${ }_{35}$ Evreiskaya avtonomnaya oblast'. Sbornik 1959 (a collection of essays, articles and poems; the publication was 160 pages long and 3,000 copies were released); Goldberg 1961: 217.

${ }^{36}$ Groussard 1958; Entretien de N. Khrouchtchev avec le correspondant du "Figaro" 1958 (brochure, 16 pages long); interview translated into English: Pinkus 1984: 61-63. For more see Estraikh 2018.

37 As cited by Pinkus 1984: 62. 
the correspondence from and to the Foreign Office, and even small mistakes (such as the incorrect title of the newspaper Birobijan Stern)..$^{38}$

(2) If they wanted to obtain precise information about the oblast (including most importantly, whether it still existed), the British had to make use of indirect data, such as through analyses of press news, listening to Soviet radio broadcasts, and confidential witness accounts. This went on even though the two states (United Kingdom and the Soviet Union) were maintaining diplomatic relations on the top level, which on the one hand illustrates the atmosphere of these relations, and on the other, the totalitarian nature of the USSR (which quite effectively rationed out the truth about the Soviet reality). The topic of Birobijan appeared not only in the correspondence of the Foreign Office with the Moscow Embassy, but also with the Tel Aviv Chancery, and in contacts with Israel's Embassy in the USSR. Copies of letters on these matters were sent to the British Middle East Office and analysed in the Information Research Department. All this indicates London's keen interest in the matter.

(3) It is interesting to ask why the British authorities devoted so much attention to a matter over which they had no influence and did not concern them directly. It seems that there could have been several reasons for this. Birobijan appeared to be a glaring example of the Soviet theory (ideological guidelines) not aligning with practice, and therefore could be used in the fight against the USSR's anti-Western propaganda. Characteristically, the oblast, although located on the peripheries and sparsely populated, for various reasons drew the attention of the USA and Israel, which is indirectly confirmed by the analysed documents of the Foreign Office.

There are no grounds for drawing firmer conclusions, but perhaps London's interest in the matter was somehow related to the British Middle East policy. As we know, in February 1953 Stalin broke off diplomatic relations with Israel. Although his successors soon re-established them, nobody knew what course Moscow would take. Birobijan was intended to be an alternative to the "Jewish national home" in Palestine. Its liquidation could have foreboded a rapprochement with Israel or, conversely, have suggested a completely different policy. It is possible that the Kremlin deliberately did not deny rumours about the oblast's liquidation in order to raise doubts. Could the British have feared potential repercussions in the Middle East, where they still had footholds? Could consultations with Sharett and the Chancery in Tel Aviv have been a reflection of these fears?

$$
\text { *** }
$$

The documents presented in this selection come from The National Archives in London, the Foreign Office collection. The first is dated 24 November 1952, and the last 11 August 1958. This edition is comprised of confidential correspondence between the British embassies in the USSR and Israel and the Foreign Office in London. Three documents were produced in the British Embassy in Moscow, one in the Foreign Office, and one in the Chancery in Tel Aviv. They basically refer to two matters: (1) the discussion about the current status of the Jewish Autonomous Oblast (whether rumours of its alleged liquidation were true) and (2) deliberations about Birobijan's actual nature (to what extent it was Jewish and autonomous).

${ }^{38} \mathrm{Cf}$. fn. 46 and 67. It is also noteworthy that the spelling of the oblast's capital city is inconsistent (Birobijan and Birobidjan). 
This edition has retained the original spelling and layout of the letters. The numbered footnotes explain lesser known terms, and provide the basic biographical data on the people involved. I have attempted to clarify some cases of unclear or doubtful issues. The lettered footnotes contain information about the document's formal features.

\section{APPENDIX}

\section{LETTER OF THE FOREIGN OFFICE (EASTERN DEPARTMENT) TO THE BRITISH CHANCERY IN MOSCOW, 24 OCTOBER 1952}

\author{
(ER 10338/1) \\ CONFIDENTIAL
}

FOREIGN OFFICE, S.W.1. 24th November, 1952.

\section{Dear Chancery,}

Your letter No. 110.7/47/52 of 23rd October ${ }^{39} 1952$ to Chancery, Tel Aviv ${ }^{40}$ copied to us and British Middle East Office, Fayid, ${ }^{41}$ about Mikunis' speech at the XIXth Party Congress. ${ }^{42}$

2. In paragraph 3 of your letter you refer to "the disappearance of the Jewish Autonomous Oblast." We would be grateful to know the grounds on which you base this statement. The only sources we have seen to support the theory that the Jewish Autonomous Oblast has been abolished are the following:

An article by Harry Schwartz in the "New York Times" of 22nd April, 1951;43

An article by Crankshaw in the "Observer" for the 21st May, 1951, which appeared to be a pick-up of the Schwartz article, declaring that the Oblast had been "suppressed," but quoting no sources; ${ }^{44}$

A "Jewish Chronicle" 45 report on the 24th August, 1951 quoting Belgrade Radio to the effect that the Oblast had been incorporated in Khabarovsk Krai.

39 A copy of the letter is kept in TNA. FO 371/98797.

${ }^{40}$ Chancery - in Anglo-Saxon tradition it is the main building which houses diplomatic representatives (legation, embassy). In this case this is a reference to the British Embassy in Israel.

41 The British Middle East Office (BMEO) dealt, among others, with coordinating activities promoting the economic and social development of British territories in the Middle East. It also provided military and diplomatic cover for the Secret Intelligence Service (MI6) in these territories. One of the offices was in Fayid, in the Suez Canal area. West 2014: 86; Barton 2014: 156-157.

42 Shmuel Mikunis (1903-1982) was one of the leaders of the Israeli Communist Party (Maki) and an MP to the Knesset (1949-1969, 1972-1974). His profile on the Knesset website: https://www.knesset.gov.il/mk/ eng/mk_eng.asp?mk_individual_id_t=507 (Accessed: 7 April 2020).

43 Schwartz 1951: 1, 20. Harry Schwartz (1919-2004) specialised in Soviet affairs. During the war he worked for the Office of Strategic Services (OSS, the CIA's forerunner). He was a lecturer at American universities and a member of The New York Times editorial board. The Soviet press denounced him as a "capitalist intelligence agent," and the USSR government denied him a visa. He was the author of Russia's Soviet Economy (London 1951); The Red Phoenix. Russia since World War II (New York 1961), and many other books. Obituary: The New York Times, 12 November 2004, https://www.nytimes.com/2004/11/12/obituaries/ harry-schwartz-85-times-editorial-writer-dies.html (Accessed: 7 April 2020).

44 Edward Crankshaw (1909-1984) was an officer of the British radio intelligence; he spent some time on a post in Moscow. In 1947-1968 he worked for the social liberal weekly The Observer, covering Soviet affairs. He was the author of many books on the history and politics of Austria, Russia, and the USSR. Obituary: The New York Times, 4 December 1984, https://www.nytimes.com/1984/12/04/obituaries/edwardcrankshaw-is-dead-at-75-author-on-soviet-and-hapsburgs.html (Accessed: 7 April 2020).

45 An English-language weekly published in London since 1841; the oldest continuously published Jewish newspaper in the world. Cesarani 1994. 
3. On the other hand, since the above reports appeared there have been references in Soviet regional broadcasts to the Jewish Autonomous Oblast. For example, the following specific instances can be cited:

On 7th August, 1951 Khabarovsk Radio mentioned that the Executive Committee of the "Jewish Autonomous Oblast" (sic.) had been awarded a Red Banner ${ }^{46}$ and cash prizes for exceeding the plan for collecting non-ferrous scrap;

On 29th September, 1952 a Birobijan broadcast referred to "the Khingan Tin Combine, the biggest combine in the Jewish Autonomous Oblast." 47

On this evidence, therefore, it would appear that the Jewish Autonomous Oblast continues to exist. The Research Department ${ }^{48}$ and Information Research Department ${ }^{49}$ have kept a careful watch on Soviet sources for indications to the contrary but so far have not found any.

4. We are sending a copy of this letter to Tel Aviv ${ }^{50}$ and the British Middle East Office, Fayid.

Yours ever,

EASTERN DEPARTMENT.

The Chancery,

British Embassy,

Moscow.

[TNA. FO 371/98797, typescript]

\section{LETTER OF THE BRITISH CHANCERY IN MOSCOW \\ TO THE FOREIGN OFFICE (EASTERN DEPARTMENT), 4 DECEMBER 1952}

$110.7 / 71 / 52$

CONFIDENTIAL
BRITISH EMBASSY, MOSCOW.

4th December, 1952

Dear Department,

Your letter ER/10338/1 of the 24th November about the Jewish Autonomous Oblast. ${ }^{51}$

2. We agree that our reference to the "disappearance" of the Jewish Autonomous Oblast was an over-simplification, and that it continues to exist as an administrative entity.

3. The indications are, however, that, with the change in the Soviet attitude towards the Jews, the original conception of the Jewish Autonomous Oblast as a second national Jewish home ${ }^{52}$ has changed radically, and that its existence at present is little more than formal.

4. We are sending copies of this letter to Tel Aviv and the British Middle East Office, Fayid.

Yours ever,

CHANCERY b- -b

46 This information is impossible to confirm. See fn. 13.

47 The Khinganolovo combine, which was mining and processing ores containing tin. It was located in Khingansk, in the north-western part of the oblast (Obluchensky Raion [district]). The deposits were discovered in 1944, and mining started a few years later. Entry: Khinganolovo, in: Gornaya entsiklopediya (http:// www.mining-enc.ru/x/xinganolovo/, (Accessed: 7 April 2020).

${ }^{48}$ Foreign Office Research Department (FORD) - see fn. 11.

${ }^{49}$ See fn. 12.

${ }^{50}$ The British Chancery in Tel Aviv. See Appendix, document 3.

${ }^{51}$ See Appendix, document 1.

52 The first Jewish national home was, naturally, Palestine. 
Eastern Department,

Foreign Office,

S.W.1.

[TNA. FO 371/98797, typescript]

a- -a Incoming mail stamp: E [Eastern Department], followed by handwritten annotation: R10338/2.

b- -b Illegible handwritten signature.

\section{LETTER OF THE BRITISH CHANCERY IN TEL AVIV \\ TO THE FOREIGN OFFICE (EASTERN DEPARTMENT), 16 DECEMBER 1952}

a- -a

$(21902 / 54 / 52)$

CONFIDENTIAL

BRITISH EMBASSY,

TEL AVIV,

16th December, 1952.

b- - b

Dear Department,

In your letter ER 10338/1 of the 24th November to Chancery at Moscow, you queried a suggestion that the Jewish Autonomous Oblast of Birobidjan had been liquidated. We had an opportunity of asking the Israel Foreign Minister ${ }^{53}$ about this last week. He said that Birobidjan still exists, but that its nature is shown by the fact that its two representatives at the recent Congress of the AllUnion Communist Party were neither of them Jews. Very few of the Jews in the Soviet Union had migrated to Birobidjan and those that did so crowded into the towns. ${ }^{54}$ The agricultural population remained the original non-Jewish inhabitants, and the non-Jews were still in the majority. ${ }^{55}$ Thus the experiment, which he said was an initiative of Kalinin, ${ }^{56}$ was a total failure.

We are sending copies of this letter to Chancery at Moscow and to BMEO Fayid. ${ }^{57}$

Yours ever,

CHANCERY.

Eastern Department,

Foreign Office,

London, S.W.1.

${ }^{53}$ Moshe Sharett (born Shertok, 1894-1965), Minister for Foreign Affairs (1948-1956), Prime Minister of Israel (1954-1955). After leaving politics, he was the Director-General of the Jewish Agency for Israel (1961-1965). Sheffer 1996.

${ }^{54}$ According to the census of $1959,16.1 \%$ (a very small minority) of the Jewish population of the oblast lived in the countryside. In comparison, the percentage of the city-dwelling Jewish population in the region was 71.8\%. Altshuler 1987: 82, 249; Abramovich [1960?]: 7.

55 This was admitted by official USSR statistics. According to the census of 1959, 14,269 Jews lived in the oblast, which amounted to only $8.76 \%$ of the total population. Altshuler 1987: 76 .

${ }^{56}$ In Soviet propaganda, Mikhail I. Kalinin was presented as a protector of the Jewish autonomy in the USSR. Formally, he occupied a high position (he was the titular head of the state as the Chairman of the Central Executive Committee, which was replaced by the Presidium of the Supreme Soviet of the Soviet Union in 1938), but in fact he had no real power and was not the one who decided these matters. Pinkus 1988: 72, 74-75; Kostikov 1979: 8-9.

57 The British Middle East Office - see fn. 41. 
[TNA. FO 371/98797, typescript]

a- -a Embossed seal of Great Britain.

b- -b Incoming mail stamp: E [Eastern Department], followed by handwritten annotation: R10338/3.

\section{LETTER OF THE BRITISH CHANCERY IN MOSCOW TO THE FOREIGN OFFICE (NORTHERN DEPARTMENT), 20 JULY 1956}

$\begin{array}{lll} & \text { a- -a } & \\ 1571 / 7 / 56 & \text { b- -b } & \text { Mositish Embassy, } \\ \text { CONFIDENTIAL } & & \text { July 20, } 1956 .\end{array}$

Dear Department,

The Israeli Ambassador, General Avidar, ${ }^{58}$ told the Ambassador ${ }^{59}$ a few days ago that he had recently paid a visit to Birobidjan, ${ }^{60}$ the so-called Jewish Autonomous Area in Eastern Siberia. You may be interested in his observations.

2. He said his impressions could be summarized by saying that of the three words in the title of Birobidjan, only the last had any reality. There was of course no question of autonomy, and there was very little that was really Jewish about the area. There was no school in which instruction was carried on in Yiddish and Yiddish was not even taught as a language in any of the schools. There was no Jewish theatre. In the bookshop in the capital of the area General Avidar could find only four books in Yiddish; the works of well-known Yiddish writers such as Sholem Aleichum ${ }^{61}$ were not available. There was one little paper in Yiddish which appeared twice a week; it was merely a reproduction of Pravda. ${ }^{62}$ There was one synagogue; this had been burnt down two months ago but General Avidar thought it was going to be repaired. Practically none of the Jewish children spoke or understand Yiddish, though the older Jews in the area seemed to speak it among themselves. ${ }^{63}$

3. General Avidar thought the Jewish population was about 30,000 out of a total population of about 100,000 . His impression was that there was a much higher proportion of Communists among the Jews of Birobidjan than in other Jewish communities which he has come across here in places like Kiev and Gomel. ${ }^{64}$

4. We are sending a copy of this letter to the Chancery at Tel Aviv.

58 Yosef Avidar (born Rochel, 1906-1995) was born in Volhynia; he was one of the leaders of the Haganah; after Israel was established, he was an officer of the Cahal (Israeli Armed Forces) and an ambassador to the USSR (1955-1958) and later to Argentine (1961-1965). He was the author of The Party and the Army in the Soviet Union (Jerusalem 1983). Y. Ro'i 2009.

59 The British Ambassador to the USSR at that time (1953-1957) was Sir William Goodenough Hayter (1906-1995). In later years, after leaving the diplomatic service, he was the author of publications about diplomacy, such as The Diplomacy of the Great Powers (London 1960), and Russia and the World. A Study of Soviet Foreign Policy (London 1970). London 2003: 288.

60 Avidar visited the oblast in June 1956. See fn. 25.

${ }^{61}$ Original spelling. It should be Sholem Aleichem (1859-1916, a Jewish writer counted among the greats of Yiddish literature).

62 Pravda daily; the official press organ of the Bolshevik party (since 1952 the Communist Party of the Soviet Union, CPSU).

63 According to the 1959 census, $39.2 \%$ of the Jewish population of the oblast considered Yiddish their mother tongue; in 1979 it was only 13.4\%. Most Jews were Russian-speaking (in 1979 - 86.5\%). Altshuler 1987: 202. Data cited in 1979: Itogi vsesouznoy perepisi naseleniya 1979 goda 1989: 146-148; Hirszowicz 1981: $57-58$.

${ }^{64}$ Gomel - an administrative centre in Belarus; the second largest city in the country after Minsk. 


\title{
Yours ever, \\ CHANCERY. \\ c- - c
}

Northern Department,

Foreign Office,

S.W.1.

[TNA. FO 371/122938, typescript]

a- -a Embossed seal of Great Britain.

In top right corner of the letter, handwritten note: $\mathrm{N}$ [Northern Department].

b- -b Incoming mail stamp: N [Northern Department].

c- -c Illegible handwritten signature.

\section{LETTER OF THE BRITISH CHANCERY IN MOSCOW \\ TO THE FOREIGN OFFICE (NORTHERN DEPARTMENT), 11 AUGUST 1958}

\author{
CONFIDENTIAL \\ a- -a \\ BRITISH EMBASSY, \\ MOSCOW. \\ b- -b August 11, 1958.
}

$(1571 / 11 / 8)$

Dear Department,

The virtual blackout on news of the life of the Jewish community at Birobidjan was broken on August 6, when Sovetskaya Rossiya carried a long article on the Jewish Autonomous Oblast in its series "R.S.F.S.R. Notebook." 65

2. After recalling the early history of the area as a Jewish national unit and making the familiar claims about the boundless resources which await exploitation, the article stresses the Jewish character of its cultural life: newspapers and radio services in Yiddish, the Sholom Aleichem Library in Birobidjan as a treasure house of Jewish literature, new Yiddish poets, etc. First names and patronymics are spelled out to establish the Jewish character of the local officialdom. In an interesting passage a collective farm chairman is quoted as saying that five new families have recently arrived from other parts of the country. He added, "We are expecting another sixty families. Let them all come, we will find room for them."

3. This glowing account does not bear much comparison with the impressions received by visiting foreigners. Orchard ${ }^{66}$ who was in Birobidjan in March 1957, was told that Jews were drifting from the oblast to the town and from the town to more developed parts of the Soviet Union. No effort had been made to rebuild the synagogue which had been destroyed by fire. The Yiddish newspaper Stern ${ }^{67}$ was sold only under the counter; the date of the last book published in Yiddish was 1948. No works of Sholom Aleichem were in stock in the town's main bookshop. A year and a half ago the Birobidjan experiment was still the dismal failure which it has been since its inception.

${ }^{65}$ For a bibliographical description see fn. 30.

66 Possibly Edward Eric Orchard (1920-2006), the first secretary of the British Embassy in Moscow in 1957-1959. The Diplomatic Service List 1968: 296; Ziman Roberts, Roberts 2005: 186.

${ }^{67}$ It should be: "Birobijan Shtern." The newspaper has been published since November 1930, two to five times a week, depending on the time period. Karasik 1992: 149. The newspaper's website: http://www. gazetaeao.ru/birobidzhaner-shtern/, (Accessed: 7 April 2020). 
4. The article goes on to contrast the rich and cultural life of Birobidjan Jews with the sorry fate of those who were enticed by Zionist propaganda to emigrate to Israel. It quotes from a letter written by an emigrant who curses the day when she left the Soviet Union, and says how much she is suffering in Israel. ${ }^{68}$

5. It is long since we have seen in the Soviet press such a well-disposed treatment of Jewish people and Jewish culture. One would like to see in this a hint of a more friendly official attitude. On the other hand, the article might possibly indicate a more active sponsoring of the "Jewish Autonomous Oblast" as a national home for Soviet Jews.

6. We are enclosing copies of this letter for F[oreign] O[ffice] R[esearch] D[epartment] and I[nformation] R[esearch] D[epartment] (2); and are also sending a copy to the Chancery at Tel Aviv.

Yours ever,

CHANCERY.

Northern Department,

$$
\text { c- - c }
$$

FOREIGN OFFICE.

\section{CONFIDENTIAL}

[TNA. FO 371/135342, typescript]

a- -a Embossed seal of Great Britain.

In top right corner of the letter, handwritten note: N [Northern Department].

b- -b Incoming mail stamp: RECEIVED IN, followed by illegible fragment,

13 AUG[UST] 1958 and handwritten annotation Ns. 1571/1.

c- -c Illegible handwritten signature.

Translated by Anna Sosenko

\section{BIBLIOGRAPHY}

\section{Archival sources}

The National Archives, London:

FO 371/98797

FO $371 / 122938$

FO $371 / 135342$

\section{Published primary sources}

Entretien de N. Khrouchtchev avec le correspondant du "Figaro" (1958), Etudes soviétiques, no. 122, Paris.

Itogi vsesouznoy perepisi naseleniya 1979 goda. Statisticheski sbornik (1989), vol. 4, part 1, bk. 1, Moskva.

Pinkus, B. (1984), The Soviet Government and the Jews 1948-1967. A Documented Study, Cambridge.

${ }^{68}$ The article states that the émigré was Rachil (née Michelson), who emigrated to Erec Israel in 1946 with her husband. If this information is true, Michelson was one of the very few USSR citizens of Jewish descent who were granted permission to emigrate at that time. According to the official statistics, between 1946 and 15 May 1948, only 262 Jews left the USSR for the future of Israel. Encyclopedia of Zionism and Israel 1971, vol. 1: 538 (Table 7). 
Ro'i, Y. (introduced and annotated by), (2009), The visit to Khabarovsk and Birobidzhan of Israeli ambassador to Moscow Yosef Avidar and his wife, Yemima Tchernowitz (1956): excerpts from Yemima diary, in: Kotlerman, B.B. (ed.), Mizrekh: Jewish Studies in the Far East, Frankfurt am Main.

\section{Press articles}

Groussard, S. (1958), Le Monde. Propos libres avec N. Khrouchtchev, Le Figaro, 9 April 1958.

Horodyński, D. (1958), Z wyprawą łowiecką do ZSRR. W Birobidżanie, Świat, no 49 (385), 7 December 1958: 18-19.

Pakhman, W. (1958), Evreiskaya avtonomiya, Sovetskaya Rossiya, 6 August 1958: 3.

Salisbury, H.E. (1954), Birobidzhan Jews Drop Yiddish, Prefer Russian, Visitor Is Told..., The New York Times, 22 June 1954: 6.

Schwartz, H. (1951), Soviet Abandoning "Jewish Homeland," The New York Times, 22 April 1951: 1, 20.

Sovetskaya Rossia Lauds Jewish Life in Birobidzhan (1958), The Current Digest of the Soviet Press, vol. 10 , no. 32 : $12-13$.

\section{Diaries and memoirs}

Horodyński, D. (1959), Syberia inaczej, Warszawa.

Linde, G., Meissgeier, S. (1960), Sibirien ohne Geheimnis, Leipzig.

Maltinsky, Kh. (1981), Der moskver mishpet iber di birobidzhaner, Tel Aviv.

Reeve, J. (1999), Cocktails, Crises and Cockroaches. A Diplomatic Trail, London-New York.

Salisbury, H.E. (1955), American in Russia, New York.

Ziman Roberts, N., Roberts, P. (2005), First Foreign Posting: Moscow 1957-1959. Letters to the Family, Manotic, Ont.

\section{Secondary sources (monographs, articles, general works)}

Abramovich, M. (1960?), Jews in the 1959 Soviet population census: an analysis, London.

Altshuler, M. (1987), Soviet Jewry since the Second World War. Population and Social Structure, New York-London.

Barton, G.A. (2014), Informal Empire and the Rise of One World Culture, Basingstoke.

Brent, J., Naumov, V.P. (2003), Stalin's Last Crime. The Plot against the Jewish Doctors, 1948-1953, New York.

Cesarani, D. (1994), The Jewish Chronicle and Anglo-Jewry, 1841-1991, Cambridge.

Defty, A. (2004), Britain, America and Anti-Communist Propaganda 1945-53. The Information Research Department, London.

The Diplomatic Service List (1968), vol. 3, London.

Encyclopedia of Zionism and Israel (1971), Patai, R. (ed.), New York.

Gessen, M. (2016), Where the Jews Aren't. The Sad and Absurd Story of Birobidzhan, Russia's Jewish Autonomous Region, New York.

Gilboa, Y.A. (1971), The Black Years of Soviet Jewry, 1939-1953, Boston-Toronto.

Goldberg, B.Z. (1961), The Jewish Problem in the Soviet Union. Analysis and Solution, New York.

Heitman, S. (1990), Jews in the 1989 USSR Census, Soviet Jewish Affairs 20 (1): 23-30.

Hirszowicz, Ł. (1981), Further Data on the Jewish Population from the 1979 Soviet Census, Soviet Jewish Affairs 11 (2): 53-61.

Israel Government Year-Book 5714/1953-54 (1953), Jerusalem.

Evreiskaya avtonomnaya oblast'. Sbornik (1959), Khabarovsk.

Gurevich, V.S., Ryanskii, F.N. (eds.) (1999), Evreiskaya avtonomnaya oblast'. Entsiklopedicheskii slovar', Birobidzhan-Khabarovsk.

Karasik, V. (1992), Evreiskaya pressa na russkom iazykie. Rossiya, 1986-1992. Bibliograficheskii spravochnik / Jewish Press in Russian. Russia, 1986-1992. Bibliographic Register, Moskva.

Kostikov, V. (1979), The People and Land of Birobidzhan, Moscow. 
Kuchenbecker, A. (2000), Zionismus ohne Zion: Birobidzhan. Idee und Geschichte eines jüdischen Staates in Sowjet-Fernost, Berlin.

Levin, N. (1988), The Jews in the Soviet Union since 1917. Paradox of Survival, vol. 2, New YorkLondon.

London, L. (2003), Whitehall and the Jews, 1933-1948. British Immigration Policy, Jewish Refugees and the Holocaust, Cambridge.

Longmire, R.A., Walker, K.C. (1995), Herald of a Noisy World-Interpreting the News of all Nations. The Research and Analysis Department of the Foreign and Commonwealth Office. A History, London.

Lustiger, A. (2004), Czerwona ksiega. Stalin i Żydzi. Tragiczna historia Żydowskiego Komitetu Antyfaszystowskiego i radzieckich Żydów, Warszawa.

Lvavi (Babitzky), J. (1965), Ha-hityashvut ha-yehudit be-birobidzhan (The Jewish Colonization in Birobijan), Jerusalem.

Maksimowska, A. (2019), Birobidżan. Ziemia, na której mieliśmy być szczęśliwi, Wołowiec.

Nivat, A. (2013), La république juive de Staline, Paris.

Patek, A. (1997), Birobidżan. Sowiecka ziemia obiecana? Żydowski Obwód Autonomiczny w ZSRR, Kraków.

Pinkus, B. (1988), The Jews of the Soviet Union. The History of a National Minority, Cambridge.

Schwarz, S.M. (1969), Birobidzhan. An Experiment in Jewish Colonization, in: Frumkin, J. et al. (eds.), Russian Jewry, 1917-1967, London: 342-395.

Shapiro, L. (1952), World Jewish Population, in: The American Jewish Year Book 53: 231-238.

Sheffer, G. (1996), Moshe Sharett. Biography of a Political Moderate, Oxford.

Srebrnik, H.F. (2010), Dreams of Nationhood. American Jewish Communists and the Soviet Birobidzhan Project, 1924-1951, Boston.

Weinberg, R. (1998), Stalin's Forgotten Zion. Birobidzhan and the Making of a Soviet Jewish Homeland. An Illustrated History, 1928-1996, Berkeley-Los Angeles-London.

West, N. (2014), Historical Dictionary of British Intelligence, 2nd ed., Lanham, Md.

\section{Internet sources}

Birobidzhaner shtern, at: http://www.gazetaeao.ru/birobidzhaner-shtern/ (Accessed: 7 April 2020).

Estraikh, G. (2018), Birobidzhan in Khrushchev's Thaw: the soviet and the western outlook, at: https:// www.tandfonline.com/doi/abs/10.1080/14725886.2018.1549196 (Accessed: 7 April 2020).

Khinganolovo, in: Gornaya entsiklopediya, at: http://www.mining-enc.ru/x/xinganolovo/ (Accessed: 7 April 2020). 